\title{
POSTFIRE RECOVERY OF TWO SHRUBS IN THE INTERIORS OF LARGE BURNS IN THE INTERMOUNTAIN WEST, USA
}

\author{
Lori L. Ziegenhagen ${ }^{1}$ and Richard F. Miller²,3
}

\begin{abstract}
Shrub canopy cover can take between 10 and $>50$ years to recover to predisturbance levels following fire in sagebrush communities. The high degree of unpredictability of shrub recovery following prescribed fires and wildfires makes it difficult to prioritize restoration efforts and develop long-term plans for restoring or maintaining the integrity of sagebrush communities. Our overall goal was to develop a hypothesis based on descriptive data that describes the temporal pattern of recruitment for 2 important shrubs, Artemisia tridentata Nutt. ssp. vaseyana (Rydb.) Beetle and Purshia tridentata (Pursh) DC., in the interiors of large burns where little seed input from surviving shrubs occurs. We had 2 primary questions: (1) are there distinct temporal patterns of recruitment in the interiors of large burns that determine the recovery rate of the shrub canopy layer for species largely dependent on seedlings for reestablishment and (2) can we generate hypotheses that explain this variation in shrub recovery rates? To address the question of recruitment, we measured shrub density and age for A. tridentata ssp. vaseyana and P. tridentata in the interiors of 4 large (>400-ha) burns. Time since fire varied from 6 to 41 years. All 4 fires burned in August and were relatively complete with few to no unburned patches. Our data indicate that (1) A. tridentata ssp. vaseyana and $P$. tridentata seed remained viable up to 4 years postfire and that (2) the rate of shrub recovery is largely determined by the success or failure of seedling establishment in the first 2-3 years following disturbance. From these data we generated a hypothesis describing 2 scenarios of postfire shrub recovery.
\end{abstract}

Key words: Artemisia, bitterbrush, Purshia, recruitment, restoration, sagebrush.

The sagebrush biome, which occupies some 62.7 million ha in the western United States (West 1983), is considered one of the most endangered (Noss et al. 1995). An estimated $50 \%-60 \%$ has been converted to either cropland, nonnative annual grasses, or woodlands (West 2000, Miller and Tausch 2001). In the last 20 years, wildfires in nonarable portions of the sagebrush biome have increased in both number and size, which can result in new steady-state annual grasslands (Westerling et al. 2006, Miller et al. in press). The loss of sagebrush communities has resulted in concern for a number of sagebrush-obligate species (Connelly and Braun 1997, Knick et al. 2005). Although we have extensive information on the deterioration in the sagebrush ecosystem, the processes of recovery are relatively unknown and expensive and may take centuries (U.S. Department of Interior 1996, Allen-Diaz and Bartolome 1998, Hemstrom et al. 2002).

Taxa that dominate the largest areas of the sagebrush biome in the Intermountain Region belong to the Artemisia tridentata Nutt. group, represented by subspecies wyomingensis, tridentata, and vaseyana (Connelly et al. 2004). Artemisia tridentata ssp. vaseyana (Rydb.) Beetle, usually occupies sites that are cooler and wetter than the sites the other 2 subspecies occupy. Purshia tridentata (Pursh) DC. is commonly associated with the A. tridentata group and is considered an important food for many wildlife species. Although the literature reports that the average time for Artemisia tridentata Nutt. to recover to near-preburn levels is $30-35$ years following fire, the range in variation is 10 to $>50$ years (Harniss and Murray 1973, Barney and Frischknecht 1974, Watts and Wambolt 1996, Nelle et al. 2000, Ziegenhagen 2004). Even within a subspecies, the variation in recovery time is high. A survey of over 50 fires in the A. tridentata Nutt. ssp. vaseyana alliance reported that the time for Artemisia canopies to approach 20\%-30\% cover ranged from 15 to $>50$ years postfire (Ziegenhagen 2004). Factors likely contributing to the rate of shrub canopy recovery are

\footnotetext{
${ }^{1}$ Department of Range Ecology and Management, Oregon State University, Corvallis, OR 97331.

${ }^{2}$ USDA Agricultural Research Service, Eastern Oregon Agricultural Research Center, 67826-A Hwy. 205, Burns, OR 97710

${ }^{3}$ Corresponding author. E-mail: richard.miller@oregonstate.edu
} 
amount of and distance from edge of unburned shrubs, abundance and viability of seed in the soil seed bank, pre- and postfire weather, postfire environment, and postfire disturbance.

Little is known about the process or temporal pattern of reestablishment for A. tridentata ssp. vaseyana and $P$. tridentata following large wildfires in the Intermountain West. Artemisia tridentata ssp. vaseyana does not crown- or root-sprout, so it is limited to reestablishment following disturbance from seed sources alone (Daubenmire 1975). Purshia tridentata is capable of resprouting from the basal crown; however, the majority of $P$. tridentata individuals growing in the A. tridentata ssp. vaseyana alliance are killed by fires (Blaisdell 1953, Nord 1965, Koniak 1985, Ziegenhagen 2004).

One square meter of A. tridentata ssp. vaseyana canopy is capable of producing over 350,000 small, wind-borne seeds (Goodwin 1956). Seed germination rates are typically high enough to exclude germination as a limiting factor in recovery (Harniss and McDonough 1976). It appears that mountain big sagebrush seed requires winter stratification that prevents germination until early spring (McDonough and Harniss 1974, Young and Evans 1978); it also appears that seedling emergence rates increase in growing seasons with higher moisture (Young et al. 1990, Schuman et al. 1998). However, growing seasons in this region are typically short, and summer desiccation is the primary factor limiting seedling survival (Daubenmire 1975, Jensen et al. 1989). This, combined with the limited dissemination distance of A. tridentata ssp. vaseyana seed, could result in many decades required for this species to reestablish within the interiors of large burn areas where few surviving shrubs occur. Seeds are disseminated primarily by wind, and the majority fall within 9-12 $\mathrm{m}$ of the parent plant but under rare conditions fall up to $33 \mathrm{~m}$ away from the parent plant (Blaisdel 1953, Mueggler 1956, Johnson and Payne 1968). Therefore, postfire establishment conditions and the availability and abundance of seed may be the primary driving factors determining the rate of shrub recovery following fire. Recovery rates where seed dissemination is limited may be dependent upon the soil seed bank.

Purshia tridentata seed, on the other hand, is large, shatters directly below the parent plant, and is dispersed mostly by granivorous rodents (Nord 1965, West 1968, Sherman and Chilcote 1972, Vander Wall 1994). Vander Wall (1994) found that rodents typically cached seeds no farther than $25 \mathrm{~m}$ from the parent plant. Purshia tridentata seedling mortality is as high as $78 \%-92 \%$ each year due to grazing rodents in the spring and desiccation in the summer (Vander Wall 1994). Although the distance of seed dissemination for this species is greater than it is for Artemisia tridentata ssp. vaseyana), soil seed pools still may be important for early establishment in large burns where distance to disseminating shrubs is $>100 \mathrm{~m}$.

The ability to predict and understand this wide variation in shrub recovery rates would provide a useful tool for restoration management. Our goal was to develop a hypothesis that describes shrub recovery rates within the interiors of large burns. To do this we measured temporal recruitment using annual growth rings for A. tridentata ssp. vaseyana and $P$. tridentata in the interiors of 4 large burns.

\section{METHods}

\section{Study Areas}

This study was conducted in the sagebrush-steppe of southeastern Oregon and northwestern Nevada (Fig. 1). The 4 study sites were located in Harney and Lake counties, Oregon, and Washoe County, Nevada, in the High Desert Ecological Province between 1400 and $2000 \mathrm{~m}$ elevation (Table 1). Average annual precipitation is $30-35 \mathrm{~cm}$ and comes mostly as winter snow and spring rain (Taylor and Hannan 1999). Fires usually occur during July, August, and early September, when dry lightning storms are common and weather conditions are hot and dry. Regionally, the majority of soils occupied by the A. tridentata ssp. vaseyana alliance are classified as either Argixerolls or Haploxerolls (Anderson et al. 1998, Miller et al. 2000). Within the 4 study sites, soils typically varied from mixed, frigid Typic Argixerolls to mixed, frigid Pachic Haploxerolls. Surface soil textures both within and across study sites ranged from sandy loams to loams to silt loams; at the 20-40-cm depth, textures range from sandy loams to clay loams (Ziegenhagen 2004).

Diagnostic species that characterized the plant associations across the 4 fires were $A$. tridentata ssp. vaseyana and P. tridentata in the shrub layer with a perennial grass understory 


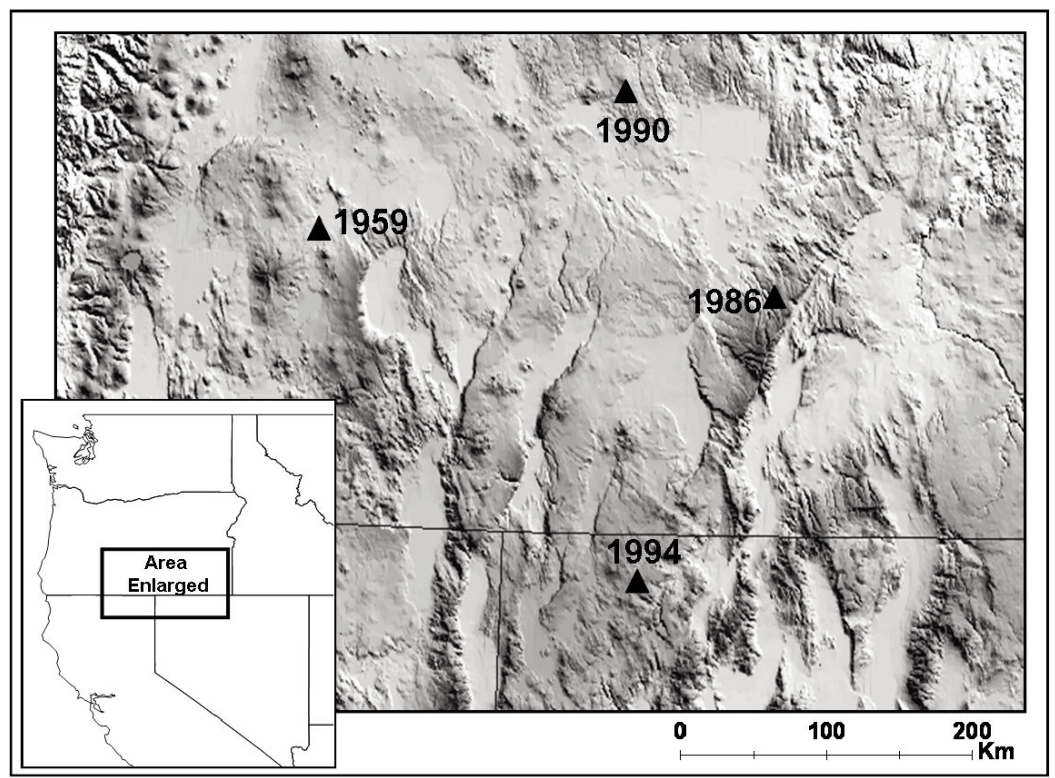

Fig. 1. The location and year of burn of the 4 study sites in central and southeastern Oregon and northwestern Nevada.

TABLE 1. Location, site characteristics, and sample size for the 4 study sites (designated by the year of burn).

\begin{tabular}{lcccc}
\hline & 1994 & 1990 & 1986 & 1959 \\
\hline Years since fire & 6 & 11 & 15 & 41 \\
Location & & & 118.56 & 121.016 \\
$\quad$ Latitude & 119.312 & 119.472 & 42.798 & 43.073 \\
$\quad$ Longitude & 41.616 & 43.646 & 1900 & 1450 \\
Elevation (m) & 2000 & 1430 & 400 & 900 \\
Size (ha) & 3200 & 32,000 & 3 & 3 \\
No. of plots & 9 & 9 & 169 & 163 \\
No. of sagebrush aged & 538 & 0 & 0 & 169 \\
No. of bitterbrush aged & 267 & & & \\
\hline
\end{tabular}

of Achnatherum nelsonii (Scribn.) Barkworth, Festuca idahoensis Elmer, and Pseudoerogneria spicata (Pursh) A. Löve. The dominance of A. nelsonii and F. idahoensis suggests that the study sites were located on the moist end of the spectrum of the A. tridentata ssp. vaseyana alliance. Three of the study areas were burned by wildfires in different years $(1994,1990$, and 1959). The fourth study area was burned by a prescribed fire in 1986. All 4 fires occurred in August, prior to A. tridentata ssp. vaseyana seed maturation but following potential seed maturation for P. tridentata. Each of the sites were large ( $>400$-ha), uniform burns with few unburned patches in the interiors (Table 1). The range in number of years since fire allowed us to capture different stages of shrub recovery. There were no records or indication that vegetation had been manipulated (i.e., sprayed, seeded, burned, or mechanically treated) prior to or following the fires. Ziegenhagen (2004) described the study sites in detail.

\section{Plot Selection}

In 2001 three to nine 0.24 -ha plots $(40 \times$ $60 \mathrm{~m}$ ) were randomly located at least $100 \mathrm{~m}$ from unburned edges of either the fire boundary or patches inside the fire boundary. The number of plots varied with size of the burn and amount of variation in aspect and slope. With a distance of $\geq 100 \mathrm{~m}$ between newly established A. tridentata ssp. vaseyana or $P$. tridentata and a potential seed source immediately following the fire, we assumed that these new establishments would have been the result of soil seed pools. 


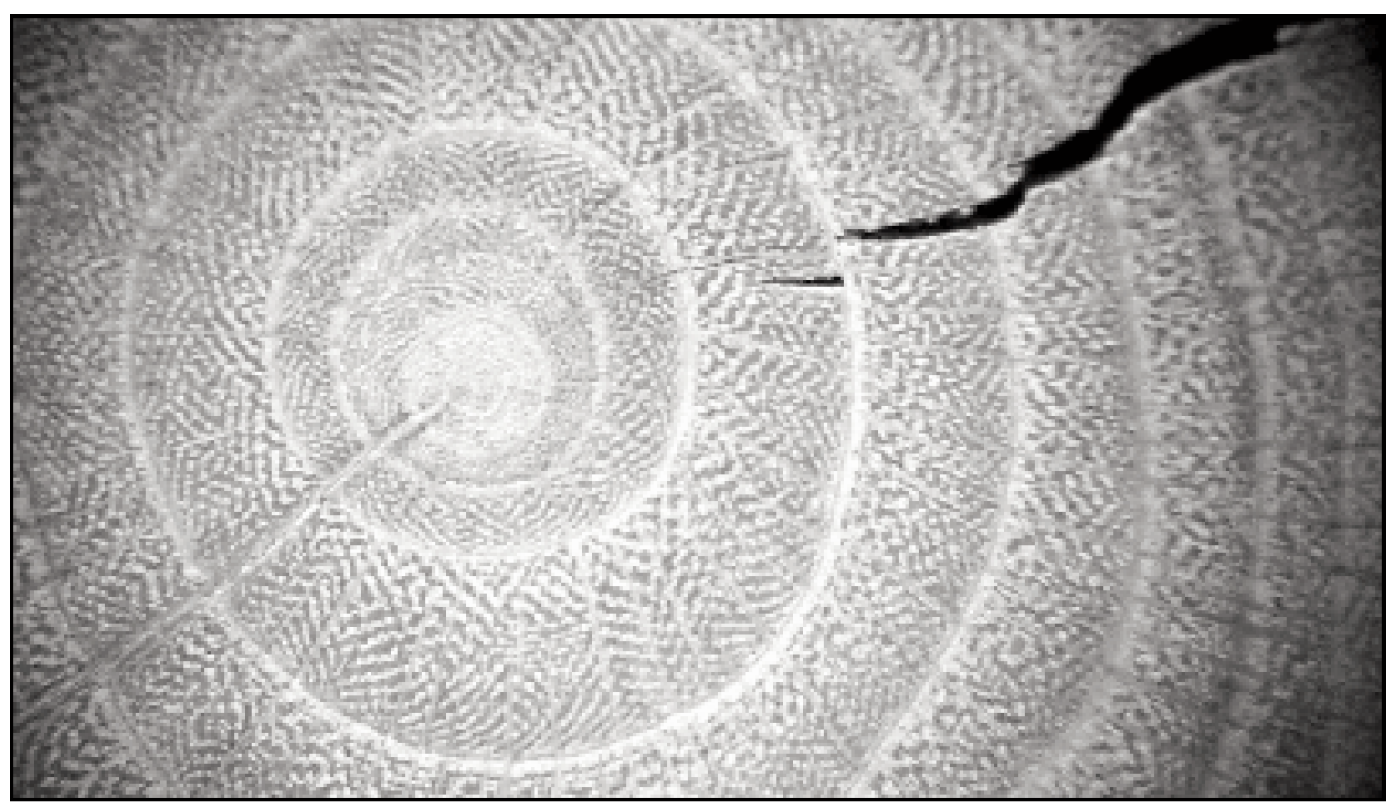

Fig. 2. Artemisia tridentata ssp. vaseyana annual growth rings and pith (10X magnification).

\section{Community and Site Characteristics}

To obtain an estimate of live-shrub canopy cover by species, we used the line-intercept method (Canfield 1941) along three 60-m transects spaced $15 \mathrm{~m}$ apart in each plot. Liveshrub density was determined using $2 \times 60-\mathrm{m}$ plots centered along the three $60-\mathrm{m}$ transects (Poulton and Tisdale 1961). Seedlings with existing cotyledons were not counted, and only those shrubs that had survived at least one growing season were included in density values. Precipitation data from the weather station located nearest to each of the 4 study sites were used to determine the percentage of average precipitation received before and after each fire and during the early years of recovery. Percentage of average precipitation was calculated by comparing a station's cropyear precipitation (September-August) to that station's long-term crop-year mean. Although these weather stations were not located on the study sites, we assumed they would provide an index of trends of annual precipitation relative to the mean for the general area.

\section{Shrub Age Determination}

Within each plot during the summer of 2001, the nearest live A. tridentata ssp. vaseyana was cut every $3 \mathrm{~m}$ along the three $60-\mathrm{m}$ transects starting at the $3-\mathrm{m}$ mark $(n=60)$. Litter layers around each crown were removed, and the level of mineral soil was marked on each shrub with a permanent marker. Shrub crowns were harvested by sawing or clipping $\geq 5 \mathrm{~cm}$ above and below ground level. Before we started largescale harvesting in the field, a dozen shrub samples were prepared and the rings were counted at the mineral-soil mark and at 2 and $4 \mathrm{~cm}$ above and below the mineral-soil mark. By doing this, we confirmed that the mineral-soil mark was an appropriate point for capturing the first year's growth ring. We did not encounter multiple stems at the mineral-soil mark.

Purshia tridentata was harvested every $3 \mathrm{~m}$ in the 1994 burn and every $6 \mathrm{~m}$ in the 1959 burn along the three $60-\mathrm{m}$ transects in each plot, and the same sampling methods applied as for sagebrush harvesting $(n=60)$. Density of $P$. tridentata in the 1959 burn was too low to sample every $3 \mathrm{~m}$, and in the 1990 and 1986 plots it was too low to adequately sample at all. Densities were also low on adjacent unburned plant communities on similar soils for the 1990 and 1986 burns (Ziegenhagen 2004). If a harvested $P$. tridentata was composed of several established shrubs emerging from the same location, the largest individual was collected. We assumed it originated from an unclaimed rodent seed cache and recorded it as such. 
TABle 2. Artemisia tridentata spp. vaseyana (ARTRV), Purshia tridentata (PUTR), Ericameria nauseosa (Pall. ex Pursh) Nesom and Baird (ERNA), and Chrysothamnus viscidiflorus (Hook.) Nutt. (CHVI) density (shrubs $\cdot \mathrm{m}^{-2}$ ) and percent cover for all shrub species and the number of shrubs aged across the 4 fires. "Other shrubs" included all other species (Ziegenhagen 2004).

\begin{tabular}{|c|c|c|c|c|c|c|c|c|c|}
\hline & & \multicolumn{2}{|c|}{1994} & \multicolumn{2}{|c|}{1990} & \multicolumn{2}{|c|}{1986} & \multicolumn{2}{|c|}{1959} \\
\hline & & $\bar{x}$ & $s$ & $\bar{x}$ & $s$ & $\bar{x}$ & $s$ & $\bar{x}$ & $s$ \\
\hline Total shrubs & Density & 0.94 & 0.44 & 0.75 & 0.42 & 1.56 & 0.72 & 1.52 & 0.18 \\
\hline ARTRV & $\begin{array}{l}\text { Density } \\
\text { \% Cover }\end{array}$ & $\begin{array}{l}0.28 \\
2.0\end{array}$ & $\begin{array}{l}0.20 \\
1.5\end{array}$ & $\begin{array}{l}0.42 \\
9.0\end{array}$ & $\begin{array}{l}0.34 \\
5.2\end{array}$ & $\begin{array}{l}0.83 \\
17.4\end{array}$ & $\begin{array}{l}0.42 \\
2.4\end{array}$ & $\begin{array}{l}0.88 \\
19.2\end{array}$ & $\begin{array}{l}0.11 \\
4.9\end{array}$ \\
\hline PUTR & $\begin{array}{l}\text { Density } \\
\text { \% Cover }\end{array}$ & $\begin{array}{l}0.10 \\
0.5\end{array}$ & $\begin{array}{l}0.05 \\
0.5\end{array}$ & $\begin{array}{l}0.03 \\
0.4\end{array}$ & $\begin{array}{l}0.04 \\
0.6\end{array}$ & $\begin{array}{l}0.00 \\
0.0\end{array}$ & $\begin{array}{l}0.00 \\
0.0\end{array}$ & $\begin{array}{l}0.15 \\
8.0\end{array}$ & $\begin{array}{l}0.07 \\
5.5\end{array}$ \\
\hline $\begin{array}{l}\text { ERNA + CHVI } \\
\quad \text { (gray and green) }\end{array}$ & $\begin{array}{l}\text { Density } \\
\% \text { Cover }\end{array}$ & $\begin{array}{l}0.40 \\
3.4\end{array}$ & $\begin{array}{l}0.32 \\
2.6\end{array}$ & $\begin{array}{l}0.13 \\
3.1\end{array}$ & $\begin{array}{l}0.08 \\
1.8\end{array}$ & $\begin{array}{l}0.31 \\
4.6\end{array}$ & $\begin{array}{l}0.23 \\
2.4\end{array}$ & $\begin{array}{l}0.52 \\
3.8\end{array}$ & $\begin{array}{l}0.23 \\
2.1\end{array}$ \\
\hline Other shrubs & $\begin{array}{l}\text { Density } \\
\% \text { Cover }\end{array}$ & $\begin{array}{l}0.16 \\
2.0\end{array}$ & $\begin{array}{l}0.13 \\
1.9\end{array}$ & $\begin{array}{l}0.17 \\
2.2\end{array}$ & $\begin{array}{l}0.13 \\
1.7\end{array}$ & $\begin{array}{l}0.42 \\
10.9\end{array}$ & $\begin{array}{l}0.14 \\
2.5\end{array}$ & $\begin{array}{l}0.02 \\
0.4\end{array}$ & $\begin{array}{l}0.03 \\
0.6\end{array}$ \\
\hline
\end{tabular}

Artemisia tridentata ssp. vaseyana and $P$. tridentata crowns were taken to the lab, where they were cut at the ground-level mark using a band saw. Cut samples were sanded with progressively finer grits on an electric belt sander (from 120 to 400 grit paper) until the cell structure was visible. Binocular dissecting scopes were used to count the annual growth rings. At least 2 separate technicians counted each sample, and they reached a consensus before recording the final age. To build the chronosequence of shrub establishment on each site, we calculated the percentage of the total harvested shrubs that established each year following the fire event. These percentages included only those shrubs that successfully established each year and do not represent the total number of seeds that may have germinated and failed. Shrub crowns with rotten or missing piths (only in the 1959 burn) were not included in the analysis, although the number of growth rings present before the rot was recorded. We were confident that all shrubs with intact piths were accurately aged to the year they established. Both species develop distinct annual rings (Fig. 2). We cross-dated a subsample of both shrub species across all 4 burns and did not encounter missing growth rings. This result may be attributed to the reduced level of intraspecific competition among established shrubs in the burns. In studying the annual rings of $A$. tridentata, Ferguson (1964) found no instance of the complete absence of a seasonal growth ring. Furthermore, false growth rings were distinguished from true growth rings by a lack of suberized cork normally laid down each winter (Diettert 1938, Moss 1940, Ferguson 1964).

\section{Data Analysis}

The percentage of total annual establishment in years following fire were compiled graphically to determine the chronology of $A$. tridentata ssp. vaseyana and $P$. tridentata reestablishment for each fire. The percentage of average crop-year precipitation was then visually compared to the chronology data.

\section{RESUlTS}

Combined cover and density of $A$. tridentata ssp. vaseyana and $P$. tridentata ranged from $2.5 \%$ to $27 \%$ and from 0.38 to 1.03 shrubs $\cdot \mathrm{m}^{-2}$ (Table 2). Fires killed nearly $100 \%$ of the preexisting A. tridentata ssp. vaseyana, with the exception of several young plants that survived the 1986 fire because they were protected in small rock crevices. All the tops were killed by fire for Purshia tridentata, but $1.5 \%$ of the plants measured resprouted from crowns. We observed an early postfire pulse in A. tridentata spp. vaseyana recruitment in the 3 most recent fires (Fig. 3). Densities ranged between 0.27 and 0.37 shrubs $\cdot \mathrm{m}^{-2}$ at the end of the third postfire growing season. Purshia tridentata followed a similar pattern of establishment in the 1994 burn (Fig. 4). However, we measured little or no recruitment for $A$. tridentata ssp. vaseyana or $P$. tridentata during the first 3 postfire years in the 1959 burn.

Recruitment declined in the third and fourth growing seasons, followed by a period of limited to no shrub recruitment for both species (Figs. 3, 4). This decline occurred despite above-average moisture conditions during this period in the 1994 and 1990 burns. 

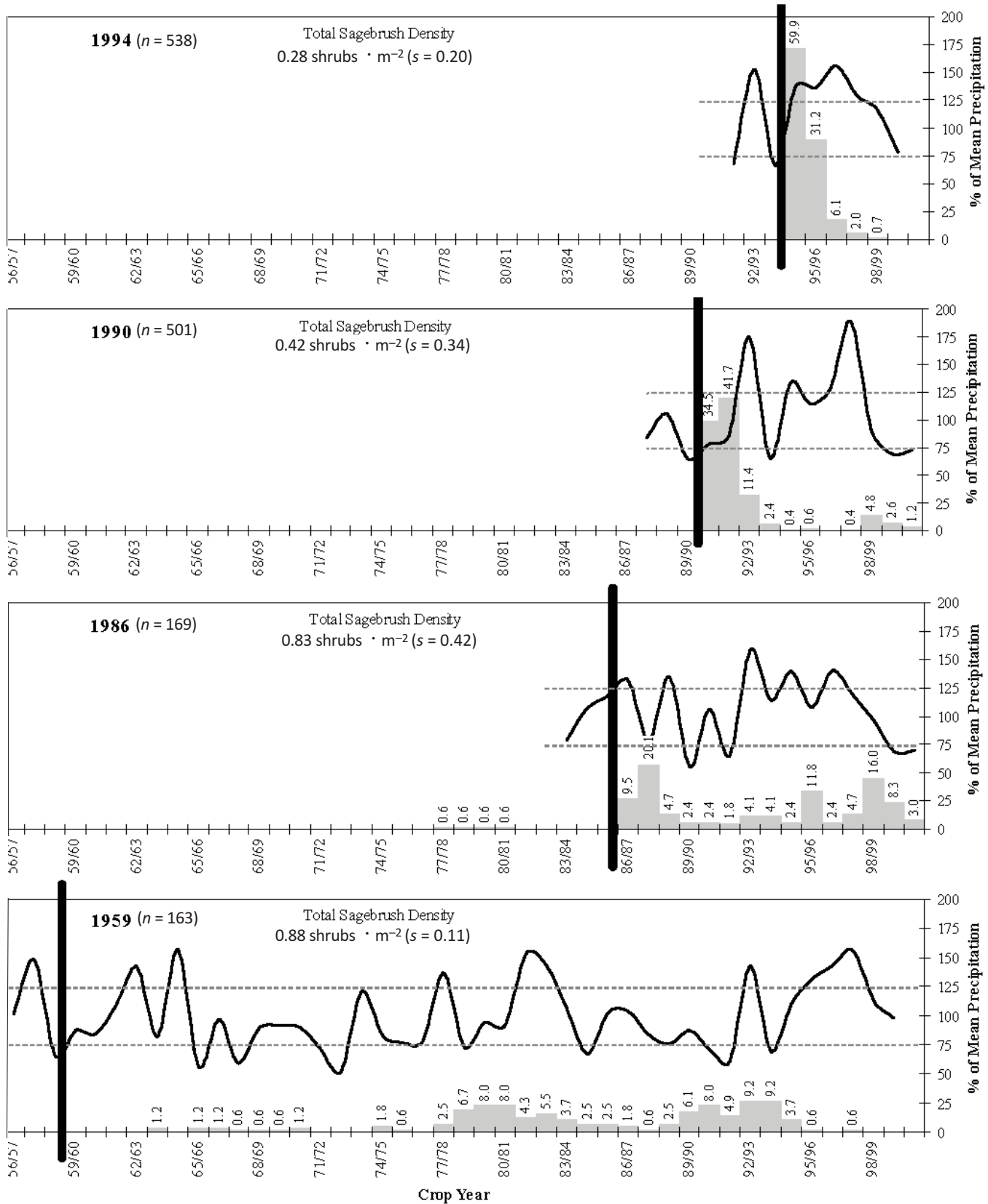

Fig. 3. The percentage of total Artemisia tridentata ssp. vaseyana to establish each year following fire (gray bars with labels) compared to the percentage of the long-term mean precipitation to accumulate each crop year (Sep.-Aug.). The dashed lines are equal to $\pm 25 \%$ of the long-term mean precipitation for each fire and are meant to approximate "normal" precipitation. The solid black vertical line represents the year of the fire event.

Very limited establishment occurred in the 1959 burn during the fourth and sixth postfire years despite above-average precipitation. For this burn, we could not verify the ages of 17 (10\%) A. tridentata ssp. vaseyana or $27(16 \%)$
P. tridentata shrubs due to stem rot. Even if these undatable shrubs did establish during the first 3 years, stocking densities would still have only been 0.08 and 0.02 shrubs $\cdot \mathrm{m}^{-2}$ for A. tridentata ssp. vaseyana and P. tridentata, 


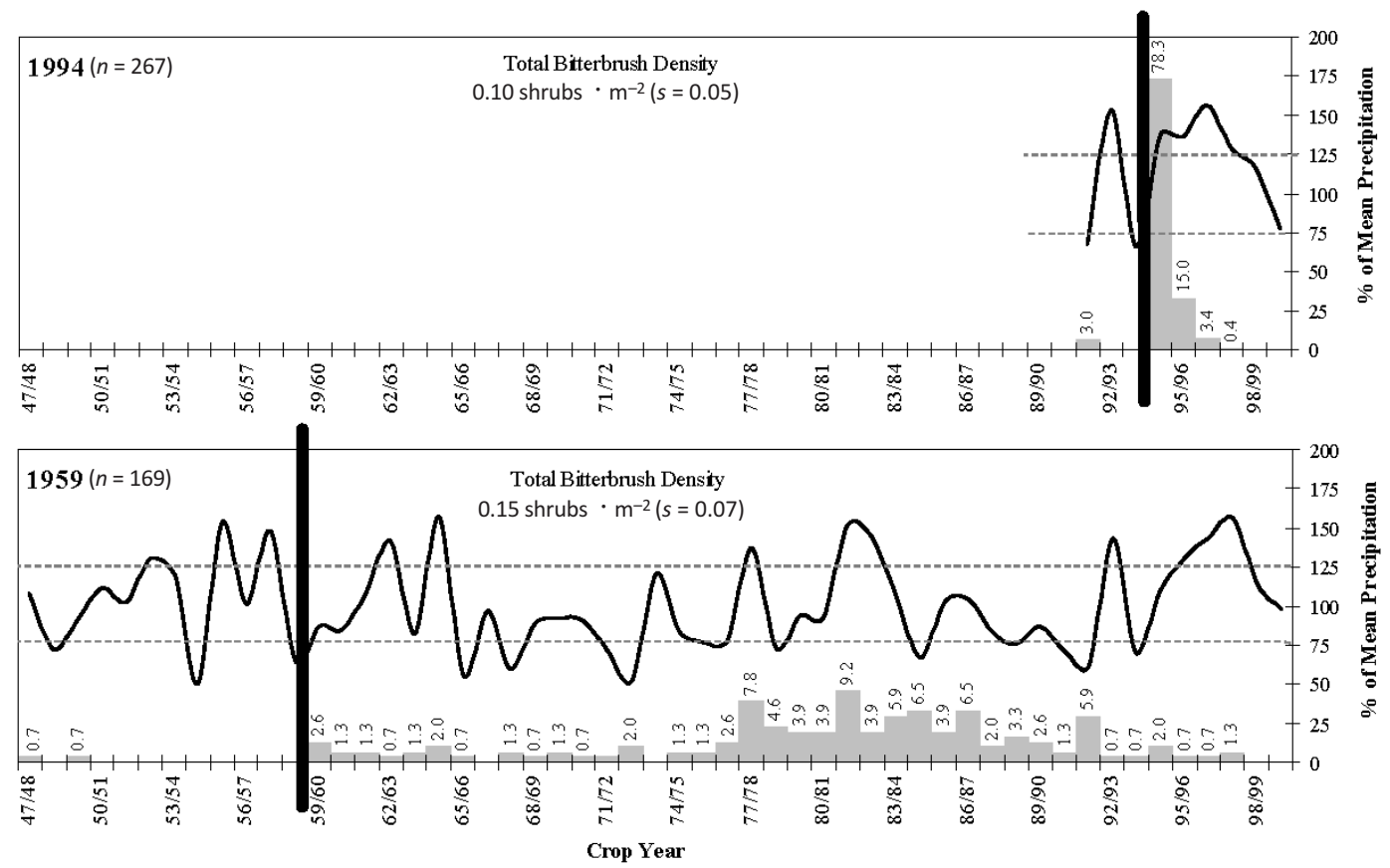

Fig. 4. The percentage of total Purshia tridentata to establish each year following fire (gray bars with labels) compared to the percentage of the long-term mean precipitation to accumulate each crop year (Sep.-Aug.). The dashed lines are equal to $\pm 25 \%$ of the long-term mean precipitation for each fire and are meant to approximate "normal" precipitation. The solid black vertical line represents the year of the fire event.

respectively, indicating limited recruitment compared to the other 3 burns. Establishment remained very low in the 1959 burn, with stocking densities of $A$. tridentata ssp. vaseyana and $P$. tridentata only 0.10 and 0.03 shrubs $\cdot \mathrm{m}^{-2}$, respectively, 20 years or more following fire. Following this period of limited recruitment, an increase in establishment was measured across the 3 older burns (Figs. 3, 4).

\section{DiscusSiON}

\section{Seed Longevity}

Our study indicated that A. tridentata ssp. vaseyana and $P$. tridentata seeds survived more than one year in the soil seed bank. The near-complete removal of mature, seed-producing shrubs in the interiors of the burns supported our assumption of a lack of seed input during the early postfire years. It is unlikely that shrubs adjacent to these large burns contributed significant amounts of seed to the interiors of the burns. The limited distance of seed dissemination would indicate that the primary seed source was from the soil seed bank. Artemisia tridentata ssp. vaseyana seed is produced in late summer and early fall and reaches maturity in early winter (Daubenmire 1975, Meyer and Monsen 1992). Fires in the sagebrush-steppe typically burn in late summer and early fall, resulting in loss of the current year's sagebrush seed crop still in the canopy. The most recent possible seed crop in the soil seed bank would have been produced in the previous fall for $A$. tridentata ssp. vaseyana. This would indicate that $A$. tridentata ssp. vaseyana seed remained viable through the second and third winters (17-29 months or more) before germination. Reports on seed longevity for A. tridentata ssp. vaseyana are varied, ranging from $<1$ year (Young and Evans 1989) to 2-3 years (Chambers personal communication). Purshia tridentata seeds ripen in spring and typically shatter in summer (Nord 1965). The most recent potential seed crop for this species would have been produced in the growing season prior to the fire. Establishment in the second and third years following fire was likely from seed remaining viable in the seedbank for at least 
1-2 years (11-23 months). Purshia tridentata seed left on the surface of the soil has decreased in viability in approximately 80 days (Ferguson 1972). However, seed from buried, unclaimed rodent caches may remain viable for several years (Vander Wall 1994). Based on the apparent lack of seed dissemination from mature plants and on the initial pulse of shrub establishment in the first 2 years following fire, we hypothesize that viable seed for the 2 shrub species studied will remain viable in the soil for at least 2 years following dissemination.

Temporal Pattern of Establishment

A pulse of shrub recruitment occurred in the first and second growing seasons following fire for 3 of the 4 burns. We did not measure an initial pulse of establishment following the 1959 burn. The early surge in establishment evident within the later 3 burns was followed by several years of limited to no establishment regardless of the amount of precipitation. In the 3 older fires this lull was followed by an increase in establishment for both species. Although our study only included 4 large burns ranging from 6 to 41 years in postfire recovery, temporal patterns of shrub establishment indicated 2 potential scenarios that may partially explain the high degree of variability in shrub establishment. We propose that the rate of recovery of $A$. tridentata ssp. vaseyana and $P$. tridentata in the interiors of large burns is dependent upon seed from the soil seed bank during the first 2 postfire growing seasons. Ziegenhagen (2004), citing data from adjacent unburned sites, suggested that full stocking density of one or the combination of both shrub species was approximately 0.95 shrubs $\mathrm{m}^{-2}(0.87-1.03,90 \% \mathrm{CI})$ across the 4 sites. In 3 of the 4 fires, densities of newly established shrubs were approximately one-fourth to onethird of preburn levels by the end of the third growing season. However, in the 1959 burn, shrub establishment was low for 3 growing seasons following the fire, resulting in a considerably slower recovery rate. Below-normal precipitation preceding the 1959 fire may have reduced seedling establishment and survival of seedlings that did establish. Shrub densities were only $10 \%$ of preburn levels 20 years after the fire. The density of shrubs that establish during the first 2 years is likely dependent upon the amount of seed in the soil seed bank and the weather conditions necessary to promote seedling establishment.

The decline in establishment in the 3 most recent fires does not appear to be the consequence of limited precipitation levels but rather is likely a result of depletion of viable seed in the seed bank and increased competition from herbaceous vegetation. The shrubestablishment lull is probably the result of weather conditions and years needed for newly established shrubs to reach reproductive maturity. Under good conditions, Artemisia tridentata ssp. vaseyana can produce seed in the second or third growing season (Daubenmire 1975), but $P$. tridentata will require 10 years to begin producing seed (Nord 1965). However, even with above-average precipitation, we observed no flowering on either species in the third and fourth years of growth within the 1994 burn area.

Following the period of limited recruitment, we recorded an increase in shrub establishment across 3 of the 4 burns. The 1994 fire probably had not yet entered this stage because of limited seed input from immature shrubs and dry conditions during 1999-2001. Since germination of A. tridentata ssp. vaseyana seed is generally not considered a limiting factor (Harniss and McDonough 1976), the initiation of the increased period of establishment can probably be attributed to a combination of increased seed input from newly established shrubs on the burn area and weather conditions allowing for establishment. Purshia tridentata followed a similar pattern of establishment in the 1959 burn area.

The second pulse in establishment began in years with average to above-average precipitation, suggesting that not only must on-site seed sources be mature enough to produce seed but that weather conditions must also be favorable for establishment. Other studies have observed similar modal establishment of A. tridentata following disturbance (Harniss and Murray 1973, Cawker 1980, Maier et al. 2001). Both timing and amounts of precipitation have been reported to affect $A$. tridentata ssp. vaseyana seedling establishment (Maier et al. 2001). Theoretically, establishment would continue until the site reached full stocking density, at which point replacement establishment may occur.

We hypothesize that shrub establishment occurs in 3 phases in the interiors of large burns 

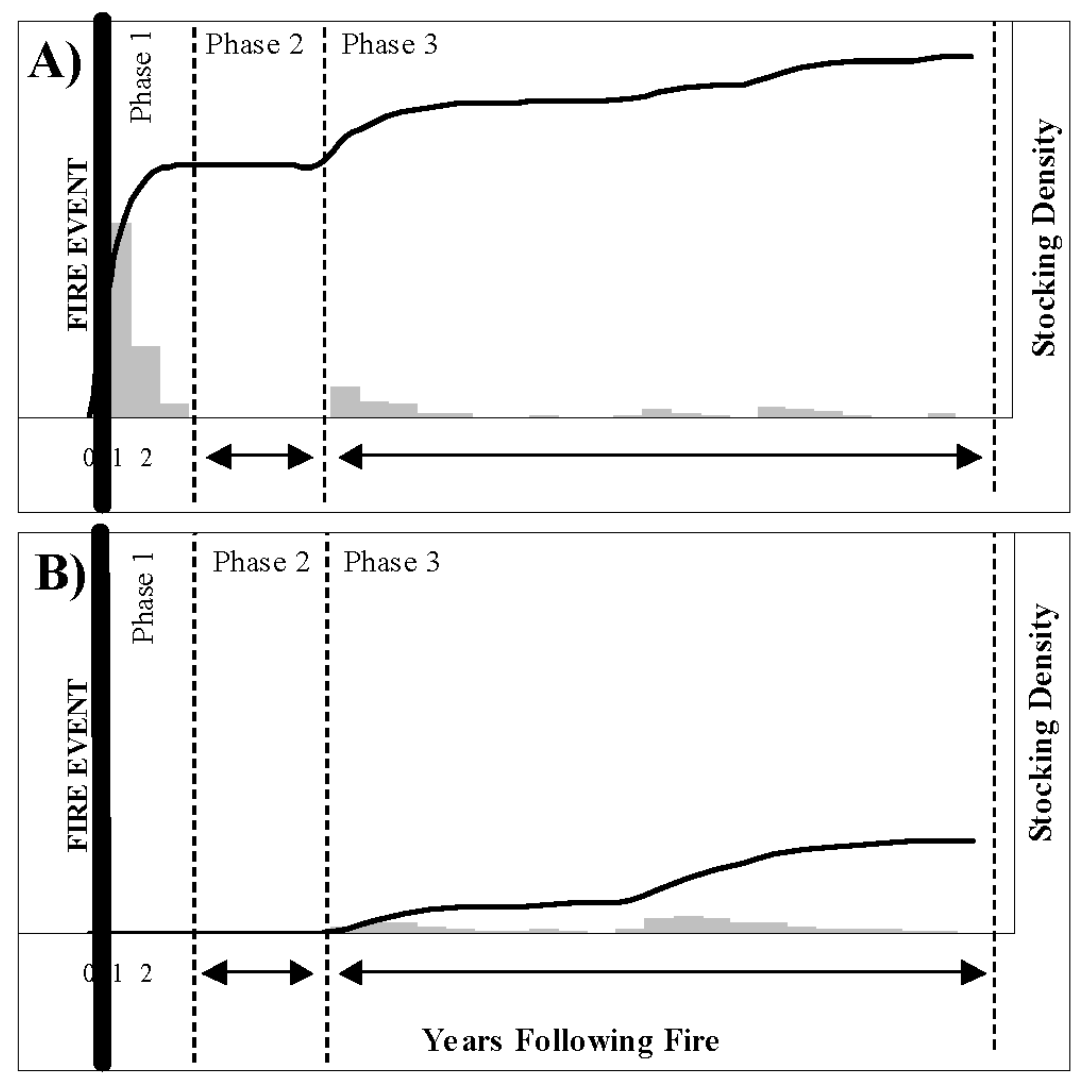

Fig. 5. Conceptual models illustrating 2 scenarios of shrub recruitment in the interiors of large fires lacking unburned patches or edges: (A) with initial establishment from soil seed pools and (B) without. Gray bars $=$ shrub establishment. Trend line $=$ percentage of maximum stocking density $\left(0.9\right.$ shrubs $\left.\cdot \mathrm{m}^{-2}\right)$ as it accumulates. Vertical dashed lines represent the theoretical separation between phases; the exact number of years between these lines would vary from fire to fire.

(Fig. 5). Shrub recruitment in phase 1 influences the rate of recovery and is dependent on the soil seed bank and pre- and postfire weather. Phase 2 represents a decline in establishment, resulting from depletion of the soil seed bank. Phase 3 is a gradual increase in establishment, resulting from seed input from maturing plants established in phase 1 . In contrast, after small or more-complex fires when potential seed input from unburned patches or edges is continuous, recovery of $A$. tridentata ssp. vaseyana and $P$. tridentata is likely driven by weather, competition, and disturbance and is potentially more rapid. In P. tridentata, granivory combined with herbivory on small plants and 2-year-old stems, which produce the current year's seed crop, can also have a large impact on seed production and establishment (Holmgren 1956, Clements and Young 1996, 2001).

\section{Research and Management Implications}

Our study of shrub ages on 4 postburn areas supports a hypothesis that recovery rates in large burns where shrub seed dispersal is limited may depend on the success of shrub establishment from the seedbed during the first 2 years following fire. Densities of onefourth to one-third of preburn levels at the end of the third year appear to be adequate to initiate a second pulse of establishment in phase 3 , possibly allowing recovery to occur within 30 years. If seedbed potential or establishment is limited during the first 2 years, managers may want to consider seeding shrubs in the interiors of these large burns.

\section{ACKNOWLEDGMENTS}

This study was funded by the U.S. Fish and Wildlife Service Sheldon National Wildlife 
Refuge; the Bureau of Land ManagementLakeview and Burns districts, Oregon; and the Eastern Oregon Agricultural Research Center, which is jointly operated by the Oregon State University Agricultural Experiment Station and the USDA Agricultural Research Service.

\section{Literature Cited}

Allen-Diaz, B., AND J.W. Bartolome. 1998. Sagebrushgrass vegetation dynamics: comparing classical and state-transition models. Ecological Applications 8:795-804

Anderson, E.W., M.M. Boreman, and W.C. Krueger. 1998. The ecological provinces of Oregon: a treatise on the basic ecological geography of the state. Oregon Agricultural Experiment Station, Oregon State University, Corvallis. SR 990.

Barney, M.A., AND N.C. FrischKnecht. 1974. Vegetation changes following fire in the pinyon-juniper type of west-central Utah. Journal of Range Management 27:91-96.

BLAISDELL, J.P. 1953. Ecological effects of planned burning of sagebrush-grass range on the upper Snake River Plains. USDA Technical Bulletin 1075, Washington, DC.

CANFIELD, R. 1941. Application of line interception in sampling range vegetation. Journal of Forestry 39:388-394.

CAWKER, K.B. 1980. Evidence of climatic control from population age structure of Artemisia tridentata Nutt. in southern British Columbia. Journal of Biogeography 7:237-248.

Clements, C.D., AND J.A. Young. 1996. Influence of rodent predation on antelope bitterbrush seedlings. Journal of Range Management 49:31-34.

. 2001. Antelope bitterbrush seed production and stand age. Journal of Range Management 54:269-273.

Connelly, J.W., AND C. Braun. 1997. Long-term changes in sage grouse Centrocercus urophasianmus populations in western North America. Wildlife Biology 3:229-234.

Connelly, J.W., S.T. Knick, M.A. Schroeder, and S.J. STIVER. 2004. Conservation assessment of the greater sage-grouse and sagebrush habitats [unpublished report]. Western Association of Fish and Wildlife Agencies, Cheyenne, WY.

Daubenmire, R.F. 1975. Ecology of Artemisia tridentata subsp. tridentata in the state of Washington. Northwest Science 49:24-35.

Diettert, R.A. 1938. Morphology of Artemisia tridentata Nutt. Lloydia 1:3-74.

Ferguson, C.W. 1964. Annual rings in big sagebrush Artemisia tridentata. Papers of the laboratory of tree-ring research No. 1. University of Arizona Press, Tucson. 95 pp.

FERGuson, R.B. 1972. Bitterbrush seedling establishment as influenced by soil moisture and soil surface temperatures. Journal of Range Management 25:47-49.

Goodwin, D.L. 1956. Autecological studies of Artemisia tridentata, Nutt. Doctoral dissertation, State College of Washington, Pullman.

HaRniss, R.O., AND W.T. MCDonough. 1976. Yearly variation in germination in three subspecies of big sagebrush. Journal of Range Management 29:167-168.
Harniss, R.O., and R.B. Murray. 1973. 30 years of vegetal change following burning of sagebrush-grass range. Journal of Range Management 26:322-325.

Hemstrom, M.A., M.J. Wisdom, W.J. Hann, M.M. RowLAND, B.C. Wales, and R.A. Gravenmier. 2002. Sagebrush-steppe vegetation dynamics and restoration potential in the interior Columbia Basin, U.S.A. Conservation Biology 16:1243-1255.

Holmgren, R.C. 1956. Competition between annuals and young bitterbrush (Purshia tridentata) in Idaho. Ecology 37:370-377.

Jensen, M.E., G.H. Simonson, and R.E. Keane. 1989. Soil temperature and moisture regime relationships within some rangelands of the Great Basin. Soil Science 147:134-139.

Johnson, J.R., And G.F. Payne. 1968. Sagebrush re-invasion as affected by some environmental influences. Journal of Range Management 21:209-212.

Knick, S.T., A.L. Holmes, and R.F. Miller. 2005. The role of fire in structuring sagebrush habitats and bird communities. Studies in Avian Biology 30:63-75.

KONIAK, S. 1985. Succession in pinyon-juniper woodlands following wildfire in the Great Basin. Great Basin Naturalist 45:556-566.

Maier, A.M., B.L. Perryman, R.A. Olson, and A.L. HILD. 2001. Climatic influences on recruitment of three subspecies of Artemisia tridentata. Journal of Range Management 54:699-703.

McDonough, W.T., and R.O. Harniss. 1974. Seed dormancy in Artemisia tridentata (Nutt.) subspecies vaseyana Rydb. Northwest Science 48:17-20.

Meyer, S.E., AND S.B. Monsen. 1992. Big sagebrush germination patterns: subspecies and population differences. Journal of Range Management 45:87-93.

Miller, R.F., S.T. Knick, D.A. Pyke, C.W. Meinke, S.E. Hanser, M.J. Wisdom, and A.L. Hild. In press. Sagebrush habitats: primary characteristics and disrupters to long-term conservation. Studies in Avian Biology.

Miller, R.F., T.J. SvejCAR, AND J.A. Rose. 2000. Impacts of western juniper on plant community composition and structure. Journal of Range Management 53:574-585.

Miller, R.F., and R.J. Tausch. 2001. The role of fire in pinyon and juniper woodlands: a descriptive analysis. Pages 15-30 in K. Galley and T. Wilson, editors, The role of fire in the control and spread of invasive species. Tall Timbers Research Station, Tallahassee, FL.

Moss, E.H. 1940. Interxylary cork in Artemisia with reference to its taxonomic significance. American Journal of Botany 27:762-768.

MUEGgLER, W.F. 1956. Is sagebrush seed residual in the soil of burns or is it wind-borne? RN-INT-35, USDA Forest Service, Intermountain Forest and Range Experiment Station, Ogden, UT.

Nelle, P.J., K.P. ReEse, AND J.W. Connelly. 2000. Longterm effects of fire on sage grouse habitat. Journal of Range Management 53:586-591.

NorD, E.C. 1965. Autecology of bitterbrush in California. Ecological Monographs 35:307-334.

Noss, R.F., E.T. LaRoE, III, AND J.M. ScotT. 1995. Endangered ecosystems of the United States: a preliminary assessment of loss and degradation. National Biological Service Biological Report 28, Washington, DC.

Poulton, C.E., AND E.W. TisDale. 1961. A quantitative method for the description and classification of range vegetation. Journal of Range Management 14:13-21. 
Schuman, G.E., D.T. Booth, and J.R. Cockrell. 1998. Cultural methods for establishing Wyoming big sagebrush. Journal of Range Management 51: 223-230.

Sherman, R.J., and W.W. Chilcote. 1972. Spatial and chronological patterns of Purshia tridentata as influenced by Pinus ponderosa. Ecology 53:294-298.

TAYloR, G.H., and C. Hannan. 1999. The climate of Oregon: from rain forest to desert. Oregon State University Press, Corvallis.

U.S. Department of InTERIor. 1996. Effects of military training and fire on habitats, prey and raptors in the Snake River Birds of Prey National Conservation Area. USDI United States Geological Survey, BLM/IDARNG Final Report, Boise, ID.

VANDER WaLL, S.B. 1994. Seed fate pathways of antelope bitterbrush: dispersal by seed-caching yellow pine chipmunks. Ecology 75:1911-1926.

Watts, M.J., and C.L. Wambolt. 1996. Long-term recovery of Wyoming big sagebrush after four treatments. Journal of Environmental Management 46:95-102.

WEst, N.E. 1968. Rodent-influenced establishment of ponderosa pine and bitterbrush seedlings in central Oregon. Ecology 49:1009-1011.

1983. North American temperate deserts and semi-deserts. Pages 321-369 in N.E. West, editor, Ecosystems of the world: temperate deserts and semi-arid deserts. Elsevier Scientific Publishing Company, New York.
2000. Synecology and disturbance regimes of sagebrush steppe ecosystems. Pages 15-26 in P.G. Entwistle, A.M. DeBolt, J.H. Kaletenecker, and K. Steenhof, compilers, Proceedings, sagebrush steppe ecosystems. USDI Bureau of Land Management Publications BLM/ID/PT-001001 + 1150, Boise, ID.

Westerling, A.L., H.G. Hidalgo, D.R. Cayan, and T.W. SWETnAm. 2006. Warming and earlier spring increases western U.S. forest wildfire activity. ScienceXpress. Available from: http://www.sciencexpress.org

Young, J.A., AND R.A. Evans. 1978. Population dynamics after wildfires in sagebrush grasslands. Journal of Range Management 31:283-289.

1989. Dispersal and germination of big sagebrush (Artemisia tridentata) seeds. Weed Science 37: 201-206.

Young, J.A., R.A. Evans, and D.E. Palmouist. 1990. Soil surface characteristics and emergence of big sagebrush seedlings. Journal of Range Management 43:358-367.

Ziegenhagen, L.L. 2004. Shrub reestablishment following fire in the mountain big sagebrush (Artemisia tridentata ssp. vaseyana) alliance. Master's thesis, Oregon State University, Corvallis. 130 pp.

Received 10 January 2008 Accepted 20 October 2008 